（日本化学会誌，1976，（8), p.1271～1276）

\title{
エチレンー酢酸ビニル共重合体膜およびそのケン化膜の 酸素透過性におよぼす水の影響
}

(1976 年 3 月 19 日受理)

\author{
箕 浦 告彦・仲 川 勤*
}

疎水性と親水性の構造を有する高分子膜の水蒸気透過性および気体透過性におよぼす本の影響を明ら かにするため本研究を行なった。13.8 および $34.4 \mathrm{~mol} \%$ の酢酸ビニル単位をるつエチレンー酢酸ビニ ル共重合体の膜 (EVAc-13, EVAc-34) およびこれらを加水分解して得られた膜（EVAl-13 f, EVAl34）を用い，水蒸気の収着量，透過性および酸素の透過性におよぼす水の影響を調べた。EVAl-13f お。 よび EVAl-34 への水蒸気の取着量は相当する EVAc のそれより多かったが, 水蒸気の透過係数, 拡 散係数は，本研究での mol\% の親水性基の道入にもかかわらず低下した。水共存に叔ける酸素の透過 係数, 拡散係数る親水性基の導入によって低下し, 蹯水性構造を有しないポリビニルアルコール，七ロ ハンとはまったく異なる挙動を示した。

\section{1 腥 雼}

一般に眯水性の膜へ親水性基を導入することによって，たとえ ばポリエチレンフィルムへアクリロニトリル，䣫酸ビニル（後で ケン化反応を行なら）をグラフトした場合》、をたビニルピリジ ンをグラフトした場合2)，セロハンおよびその酢酸エステルの場 合8)にみられるように，水の溶解度が增加し，水蒸気の透過性が 增加する。

著者の一人はすでKエチレンー醀酸ビニル共重合体 (EVAc) 膜, およびそれらの瞙のケン化によって得られたエチレンービニルフ ルコール共重合体 (EVAl) 膜に対する各種の気体の透過係数, 拡 散係数，溶解度係数を測定した。この結果， $13.8 \mathrm{~mol} \%$ の酶酸 ビニルを含有する EVAc 膜を゙ン化することにより気体透過係 数が約 $1 / 30$ に滅少し，さらに興味深いことには，ヒドロキシル 基が生成したにるかかわらず，透湿カッブを用いる簡単な測定で 透湿度も約 $1 / 20$ に減少するといら結果を報告した4)。

そこで本研究では，EVAc 膜，EVA1 膜に対する水蒸気透過性 をさらに詳細佂研究しまた酸素透過炕拈よぼす水の影響も检討 した。EVAl 膜中の水が，七ゅハンやポリビニルフルコール膜に 生けると同様の効果を示すならば，酸素透過性恃水共存によって いちじるしく増大するはずである。EVAI 膜のような蹯水性構造

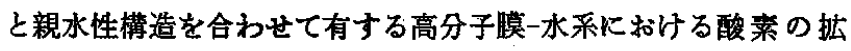
散, 透過性は生体高分子膜へのアプローチの面からも與味深いと 思われる。

* 工業技衔院 䡈品科学研究所, 144 東京都大田区下丸子

1) C. E. Rogers, J. Polym. Sci., Part C, No. 10, 93(1965).

2) V.Stannett, J. L. Williams, A. B. Gosnell, J. A. Gervasi, J.Polym. Sci., B 6, 185(1968).

3）高分子学会編, “材料と水分ハンドブック”, 共立出版(1968) p. 338.

4）仲川 勤, 日化, 1974, 147 .
これまで，水共存下での高分子膜の酸素逰過性については，溶 存酸素計をセンサーとして测定した簡単な報告があるのみであ る5) 7)。一方, Aiba 58) は溶存酸素㖕の原理に基ついた装置をつ くり, 二三の膜の酸素の透過を測定したが，膜の着脱に難点があ る。

そこで著者らは, Aiba らの装䁇を改良し, 高分子䠑の水共存 下における酸素の透遇性を容易に測定しらる測定装稙を試作し， EVAc 膜, EVAl 膜について㵋定するととるに，親本性高分子膜 であるポリビニルアルコール膜, セロハン, 悚水性高分子膜であ るポリエチレン膜, ポリスチレン瞙, さらに水共存下での酸素透

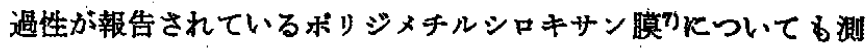
定した。

\section{2 実験}

\section{1 エチレンー酢酸ビニル共重合体膜}

エチンンー酢酸ビニル共重合体は三井石油化学(株)およ゙クラ レ(株)から供与されたるので， NaOH-HCl 逆滴定法により醀酸 ビニル含量を調べた結果， 13.8 および 34.4 mol\% であった（以 下それぞれ EVAc-13 および EVAc-34 と略記する)。これをト ルェンに溶解して，水銀上に浮かペたガラス板上にキャストして $20^{\circ} \mathrm{C}$ で亦膜した。

得られた瞙の厚さは, EVAc-13 膜で 0.060〜0.160 mm, EVAc34 嗼で $0.193 \mathrm{~mm}$ である。

笕燥した膜の比重は，浮沈法により湘定した結果，EVAc-13

5) H. Yasuda, W. Stone, Jr., J. Polym. Sci., A-1, 4, 1314 (1966).

6) H. Yasuda, ibid., 5, 2952(1967).

7) S. T.Hwang, T.E. Tang, K. Kammermeyer, J.Macromol. Sci., Phys., B 5, 1(1971).

8) S. Aiba, M. Ohasi, S. Y. Huang, Ind. Eng. Chem. Fundam., 7, 497(1968). 
膜では水-ェタノール系で $0.975 \mathrm{~g} / \mathrm{m} l, \mathrm{EVAc}-34$ 膜では塩化ナ トリウム皮溶液で $1.098 \mathrm{~g} / \mathrm{ml}$ である。

\section{2 エチレンービニルアルコール共重合体膜}

EVAc-13を膜の状態でナトリウムメトキシド溶液に浸潰し， $20^{\circ} \mathrm{C}, 20$ 時間ケン化させた。文応後, 膜を取り出し, メタノール で洗浄したのち，10\% 塩酸水溶液に浸漬し，ついで水洗して真 空乾嬠した。以下この膜を EVA1-13f 膜と略記する。

反応は膜の内部まで完全に進んでいることが，赤外吸取スペク トルの变化およびローダミン $6 \mathrm{G}$ による染色後の断面観察から 確認された。

EVAc-34 をメタノールK溶解して，ナトリウムメトキシドK よりケン化反応を行ない，さらにこの系に水を加えて反応させ た。反応終了後, 水で洗浄し，10\% 塩酸水楁液飞浸清し，ついで 水洗して真空乾燥した。この生成物をジメチルスルホキシドに溶 解し、ガラスフィルターで沪過し, 水中に滴下して沈股させて精 製したのち, 乾燥し,ジメチルスルホキシドに再溶解し, 製膜し た。以下この膜を EVA1-34 膜と略記する。

得られた瞙の厚さは, EVA1-13 膜で $0.077 \mathrm{~mm}$, EVAl-34 膜で $0.033 \mathrm{~mm}$ である。

畭龽した膜の比重は, 浮沈法により測定した結果, EVAl-13 f 膜では水ーエタノール系で $0.971 \mathrm{~g} / \mathrm{m} l, E V A 1-34$ 膜ではェタノ 一ル-四塩化炭素系で $1.120 \mathrm{~g} / \mathrm{ml}$ である。

2.3 ボリジメチルシロキサン膜，ポリスチレン膜，ボリエチ レン膜, ボリヒニルアルコール膜およびセロハン

ポリジメチルシャキサン膜として, Dow Corning 社製無補強 サイラスティック医用シートを用いた。膜の厚さは，0.128，

0.266, および $0.594 \mathrm{~mm}$ である。

ポリスチレン膜, ポリエチレン膜, ポリビニルアルコール膜拉 よびセロハンは，市眅の包装用フィルムで，脱の厚さは，それぞ れ $0.030,0.050,0.036$ 扩よび $0.025 \mathrm{~mm}$ である。

\section{4 酸素電枉法による透通实駼}

高分子膜を境界として，電極のある側飞電解液，外側飞酸素を 含を液体あるいは酸素ガスを接触させ，瞙を透過してきた酸倠量 を测定する方法として，電極反応による電流を測定する方法があ クここれまで一定の膜（たとえばフッ素化炭化水素膜）を電極に 固定し，溶存酸素計として実用されている。

図1 亿著者らの試作した電極の構造を示す。電極棒仙約 $15 \mathrm{~cm}$ の銀製パイプの一端に絶縁材を介して白金除極を取り付けたるの でこれをステンレススチール製の保護管に装てんする。真空技 術て用いられているニンプレッションシールを応用して, 膜の着 眖，白金陰極面との䀡の密着を容易にした。さらに本中で高度に 膨潤する膜，たとえばセロハンや橋かけポリビニルアルコール膜 でも測定できるように工夫した。

実験装置を因 2 に示し，測定操作を以下に述へる。保護管に膜 を装てんし， $0.5 \mathrm{~N}$ の塩化カリウム水溶液を入れ，電極棒を㨂入 する。これを図 2 の の位笡に固定する。電流が測定できるよう に配線し，分解䉓圧として $-0.7 \mathrm{~V}$ を印加する。 $\mathrm{H}$ から窒素ガ スを尊入し，蒸留水Mを窒素ガスで飽和すると，電流值は漸近的 に0になる。完全に0になったのを確珰したのち，Hから酸素ガ スを流し始めると同時に，あらかしめ酸素ガスで飽和させておい た蒸留水をこの容器 $\mathrm{L}$ Kれ，蒸留本 $\mathrm{M}$ を酸素ガスで飽和させ る。この時間を 0 として，電流の增加を記録する。なお，澌定中

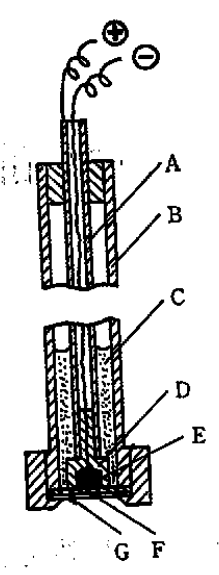

Fig. 1 Profile of electrode

A : $\mathrm{Ag}$ (anode), B : Outer pipe (stainless steel),

$\mathrm{C}: 0.5 \mathrm{~N} \mathrm{KCl}$ solution, D : Insulator, E : Pt(cathode), F : Membrane, G : Supporter

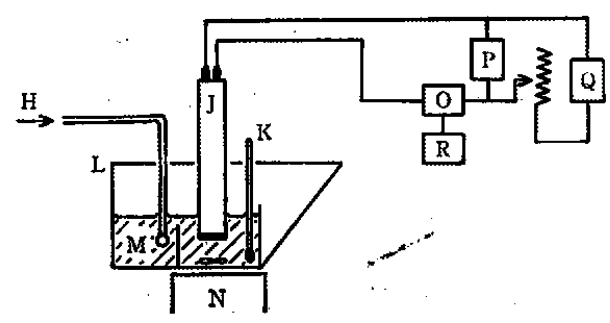

Fig. 2 Schematic diagram of experiment $\mathrm{H}: \mathrm{N}_{2}$ or $\mathrm{O}_{2}$ inlet, $\mathrm{J}$ : Electrode, $\mathrm{K}:$ Thermometer, $\mathrm{L}$ : Glass equipment, $M:$ Distilled water, $N$ : Magnetic stirrer, $0:$ Micro ammeter, P: Voltmeter, Q: Dry cell, $\mathrm{R}:$ Recorder

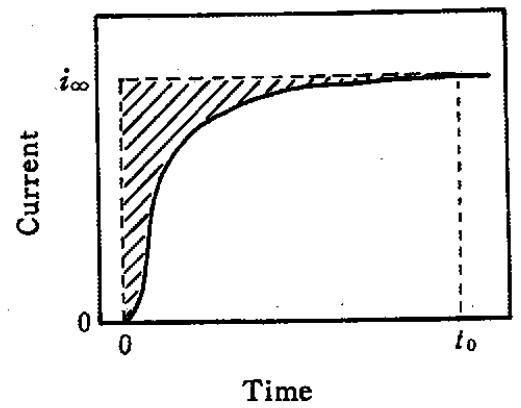

Fig. 3 Determination of diffusion coefficient by oxygen electrode method

は蒸留水をつねに一定速度でかきぜた。

この方法では, 图 3 の上らな時間対電流の微分透過曲線を得 る。この微分透過曲線の定常電流值 $i_{\infty}$ より，(1)式によって透 過你数 $P\left(\mathrm{~cm}^{3}(\mathrm{STP}) \cdot \mathrm{cm} / \mathrm{cm}^{2} \cdot \mathrm{sec} \cdot \mathrm{cmHg}\right)$ を，(2)式炕よって拡 散俰数 $D\left(\mathrm{~cm}^{2} / \mathrm{sec}\right)$ を計算した

$$
\begin{aligned}
& P=\frac{i_{\infty} \cdot l}{N \cdot F \cdot A \cdot p_{\mathrm{B}}} \\
& D=\frac{i_{\infty} \cdot l^{2}}{6\left(i_{\infty} \cdot t_{0}-q_{\infty}\right)}
\end{aligned}
$$

ここで, Nは反応に関与する電子数で酸素電極の場合は $4, F$ は 
Faraday 定数 (96500Dーロン/当量)， $A$ は陰極面積 $\left(\mathrm{cm}^{2}\right), l$ 慔の厚さ $(\mathrm{cm}) ， p_{\mathrm{g}}$ は膜が蒸留水と接している表面の酸素分正 $(\mathrm{cmHg}), t_{0}$ は $i_{\infty}$ K達するまでの洔間 $(\mathrm{sec})$ である。 $q_{\infty}$ は $\int_{0}^{l_{0}} i_{\mathrm{t}} \mathrm{d} t$ であり, したがって(2)式の分母のカッコ内は, 図3の 斜線を引いた部分の面積を示すことになる。

溶解度俰数 $S\left(\mathrm{~cm}^{3}(\mathrm{STP}) / \mathrm{cm}^{3} \cdot \mathrm{cmHg}\right)$ は

$$
S=\frac{P}{D}
$$

を用いて計算した。

白金電極の面䅡は $0.190 \mathrm{~cm}^{2}$ であり，実呀装置全体を $20^{\circ} \mathrm{C} \mathrm{K}$ 調節した。

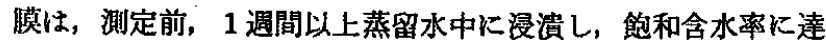
したるのについて測定した。

\section{5 収筩および透過実禹}

収着装管怯，石英バネバランスによる重量法のるのである。収 着量は $n(\mathrm{~g} / \mathrm{g}$ ポリマー) で表わす。

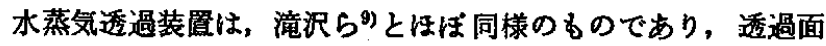
積は $18.09 \mathrm{~cm}^{2}$ である。透過係数 $P\left(\mathrm{~cm}^{\mathrm{s}}(\mathrm{STP}) \cdot \mathrm{cm} / \mathrm{cm}^{2} \cdot \mathrm{sec}\right.$. $\mathrm{cmHg}$ ）は次式を用いて計算した。

$$
P=\frac{273}{T} \times \frac{V}{A} \times l \times \frac{1}{p} \times \frac{1}{760} \times \frac{\mathrm{d} h}{\mathrm{~d} t}
$$

ここで, $T$ は測定の室温の絶対温度 ( $\mathrm{K}$ ), $V$ は低圧㑡の容積 $\left(\mathrm{cm}^{3}\right), A$ 性透過面積 $\left(\mathrm{cm}^{2}\right), \quad l$ は膜の厚さ $(\mathrm{cm}), \quad p$ は高王側 の王力 $(\mathrm{cmHg}), \mathrm{d} h / \mathrm{d} t$ は透過曲線の定常状態部分の直線の勾配 $(\mathrm{mmHg} / \mathrm{sec})$ である。拡散係数 $D\left(\mathrm{~cm}^{2} / \mathrm{sec}\right)$ は，後に述べる水蒸 気の収着等温曲線か ら溶解度保数 $S\left(\mathrm{~cm}^{\mathrm{a}}(\mathrm{STP}) / \mathrm{cm}^{3} \cdot \mathrm{cmHg}\right)$ を 求め，（3）式から計算した。

周が乾燥した状態での酸秦の透過率測定は，高真空系を用いる 真空一加圧法を用いた ${ }^{10)}$ 。透過面積は $15.89 \mathrm{~cm}^{2}$ である。透過係 数 $P$ は (4)式を用いて計算した。拡散係数 $D$ は次式を用いて諳算 した。

$$
D=\frac{l^{2}}{6 \theta}
$$

ここで, $\theta$ は透過曲線から得られる荤れ時間 $(\mathrm{sec})$ である。溶解 度係数 $S$ 法，(3)式から計算した。

\section{3 結果および考察}

\section{1 水蒸第の收嘘}

EVAc 膜就よび EVAl 膜について, 水蒸気の収着等温曲線を 因 4 亿示す。EVAc-13 膜护よび EVAc-34 膜は同し収着量を示 した。EVAl-13 f 膜は，水酸基が生成したため，EVAc-13 膜よ り収着量が増加している。また，EVA1-34 膜は親水性高分子偟特 有のシグモイド型取着曲線を示し，EVAc-34 膜にくらべて収着 量が增加している。この結果から，EVAc をケン化することによ ク明らかに親水性が增大したことがかかる。

\section{2 水蒸笑の透過性}

高压側水蒸気印力を 0.654 お よび $1.548 \mathrm{cmHg}$ に設定した場 合の透過保数打よび濃度平均拡散保数を表 1 に示す。EVAc-13

9) 潼沢 章, 谷岡明彦, 高分子化学, 28, 24(1971).

10) V.Stannett, M.Szwarc, R. L. Bhargava, J.A. Meyer, A. W. Myers, C.E. Rogers, "Tappi Monograph SeriesNo. 23", Tappi, New York (1962)p. 3.

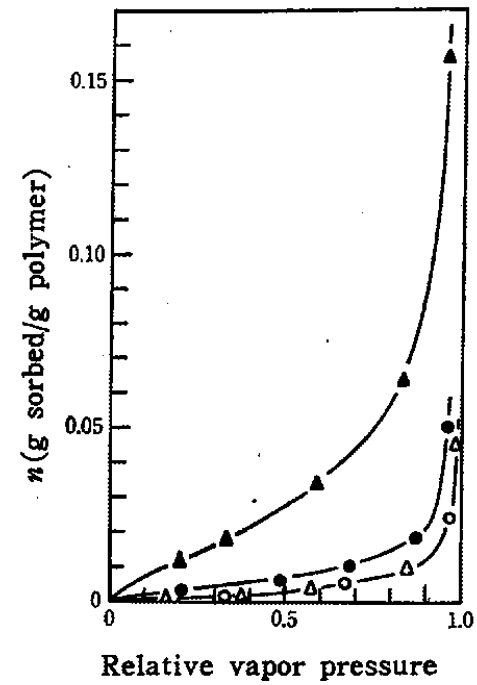

Fig. 4 Sorption isotherms of water vapor

$$
\begin{aligned}
& \Delta: \text { EVAl-34, }: \text { EVAl-13 f, } \triangle: \text { EVAc-34, } \\
& \mathrm{O}: \text { EVAc-13 }
\end{aligned}
$$

\begin{tabular}{|c|c|c|c|c|}
\hline \multirow{2}{*}{ Membrane } & \multicolumn{2}{|c|}{$0.654 \mathrm{cmHg}^{(a)}(0.37)^{b)}$} & \multicolumn{2}{|c|}{$1.548 \mathrm{cmHg}^{a)}(0.88)^{b)}$} \\
\hline & $P^{c)}$ & $D^{d)}$ & $\mathbf{p}^{\text {c) }}$ & $\mathrm{D}^{d)}$ \\
\hline EVAc-13 & 8.41 & 343 & 8.72 & 88.0 \\
\hline EVAl-13f & 0.371 & 4.05 & 0.410 & 2. 75 \\
\hline EVAc-34 & 1. 21 & 36.0 & 1.30 & 11.8 \\
\hline EVA1-34 & 0.0473 & 0.109 & 0.544 & 0.624 \\
\hline
\end{tabular}

Table 1 Permeability coefficients and diffusion coefficients of water vapor

a) Ingoing water vapor pressure.

b) Relative vapor pressure.

c) $\times 10^{-7}\left(\mathrm{~cm}^{3}(\mathrm{STP}) \cdot \mathrm{cm} / \mathrm{cm}^{2} \cdot \mathrm{sec} \cdot \mathrm{cmHg}\right)$

d) $\times 10^{-9}\left(\mathrm{~cm}^{2} / \mathrm{sec}\right)$

膜および EVAc-34 膜は，相対蒸気圧を増すと，拡散俰数は減少 している。高い相対蒸気圧下での拡散係数の減少は, 眯办性高分 子に特徽的であり，水分子の会合のためであろ ${ }^{111}$ 。EVAc-13 膜のヶン化により，透過俰数住いずれの蒸気圧下です約 $1 / 20$ K なりまた EVAc-34 膜についてす，ケン化により蒸気圷の低いと ころで約 $1 / 20$ 高いところで約 $1 / 2$ になっている。親水性基の導 入に起因与る水蒸気の収着量の堌加すなわら水蒸気の溶解度係数 の增加にるかかわらず,このよらな透過係数の減少は詓散俰数の 大きな滅少に起因している。

EVA1-13 f 膜は膜の状態でケン化を行なって得たるのである が，この膜の無定形領域はポリエチンン成分の無定形部分および ポリ酢酸ビニル成分からなると考えられる。膜の状態でらン化を 行ならと無定形領域のフセトキシル基がヒドロキシル基にかわる が、これはそのまま無定形領域存在しているはずである゙。そ してこのヒドャキシル基の周囲をポリエキレン成分，すなわら柾 水性構造の炭化水素がとりまいているような構造をとっているの であろう。したがってわずかに水の収着量は増加してる，ヒドロ キシル基の水素結合を切るに十分でなく，払散係数が減少するる のと思われる。

松本ら ${ }^{121}$ はVAc を溶液中で加水分解し，得られた"EVAl 固

11）滝沢 章，浜田敏裕，下川順造，高分子化学，28，751 (1971). 
体には混晶が存在していることを報告している。このことから， 同様の方法で加水分解し，得られた EVAl を容媒に溶かしキャ ストして得られた EVAl-3、膜には, 生じたヒドロキシル基がこ の混晶中に密度高く不均一に分布しているすのと考えられる。こ の混晶は水蒸気圧の低いときには水分子の拡散を抑制している が, 水蒸気王を高めると溜晶が徐々氏破壊され, 水分子の可塑化 作用す増大し，払散係数が増大するのであろう。かし，EVA134 膜の拡散係数はもとと結晶化度の低いEVAc-34 膜 ${ }^{19}$ の拡 散係数より小さい。

したがって㻋水性高分子である EVAc が EVAl-13f のよう に膜の状態でまた EVA1-34 のように均一系でのケン化反応によ り EVAl になり，氷の収着量は增加したにもかかわらず，新し

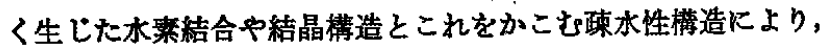
水蒸気の透過係数はむしろ減少したと考光られる。

\section{3 水共存下にむける酸素の造過性}

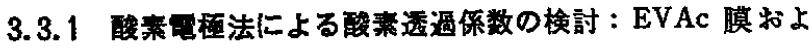

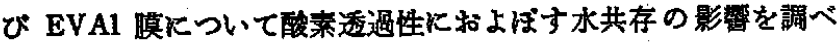
る前に, 気体透過性に扣いて水共存の影響がないと考えられるポ

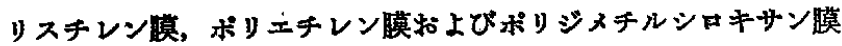
について, 著者らの試作した酸素電極装置を用いて膜が水に接し ている场合の酸素の透過係数を求め, 一方, 漧燥状悲の膜に対す る酸甞の透過係数とを比較し、これらの値が一致することをまず 確かぬた。

図 5 亿酸素電極装置を用いた場合のポリジメチルシロキサン膜 に対する透過曲線の一例を示す。この透過曲線の平衡電流值から （1）式を用いて透過係数を計算した。ポリスチレン膜，ポリェチ レン膜については透過係数を表 2 に示し，またポリジメチルシロ キサン膜については，膜の厚さの逆数に対する透過係数の逆数を 図6に示した。表 2 から、ポリスキレン，ポリェキレンいずれの 膜においても，軽㫵状㷫の膜に対する酸素の透過俰数と，水が共 存する状態での膜に対する酸菜の透過係数とがよく一致すること が諗められる。しかし, ボリジチルシロキサン膜では, 乾燥状 熊にある膜の酸素透過係数と水が共存する状態でのそれとが一致 せず, 瞙の厚さを無限大に外㨉したとさの透過係数が競燥状態に ある膜の透過係数に一致する結果が得られた。

Hwang らクは，著者らの方法すなわち電梗に測定試料を密着さ せる方法とは異なり,膜を水中に保持し, 膜の透過側の酸素漉度の 変化を溶存酸素計を用いて測定する方法により, 著者らと同様の 結果を得ている。このようにポリジンルシャキサン膜の呺莫の厚 さを無限大にしたときに乾燥状態の酸案の透過係数と一致するこ とは、ポリジチルシャキサン膜の酸素の拡散係数之水の境界膜 の酸素の拡散係数が近い值にあることによるすので，璄界瞙が酸 素透過に対する抵抗を有しているためである。もし膜の酸素の拡 散係数がこの水の境界膜の酸素の拡散係数より十分小さければ, この境界膜の存在を無視できることになり，酸素電極法で得られ た健は，永共存下の膜の酸索透過係数として，高真空法による乾 燥状態の值と比較できるすのである。

したがって，一般に水共存下での親水性高分子膜の酸素透過係

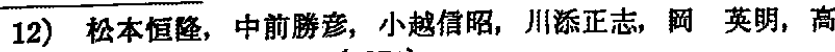
分子化学, 28, 610(1971).

13) P.M. Kamath, R.W. Wakefield, J.Appl. Polym.Sci., 9, 3153(1965).
Table 2 Comparison of permeability coefficients ${ }^{a)}$ of oxygen

\begin{tabular}{lcc} 
& Polystyrene & Polyethylene \\
\hline High vacuum method & $2.1 \times 10^{-10}$ & $2.7 \times 10^{-10}$ \\
Oxygen electrode method & $2.0 \times 10^{-10}$ & $2.7 \times 10^{-10}$
\end{tabular}

a) $\mathrm{cm}^{3}(\mathrm{STP}) \cdot \mathrm{cm} / \mathrm{cm}^{2} \cdot \mathrm{sec} \cdot \mathrm{cmHg}$

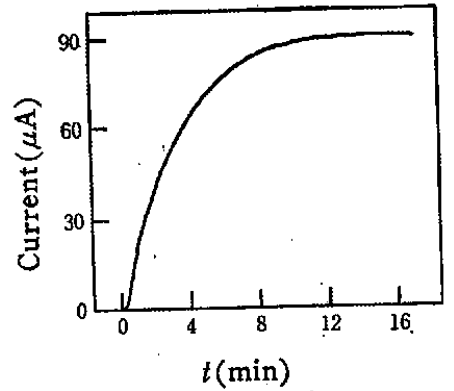

Fig. 5 Permeation curve for polydimethylsiloxane membrane

Membrane thickness is $0.594 \mathrm{~mm}$.

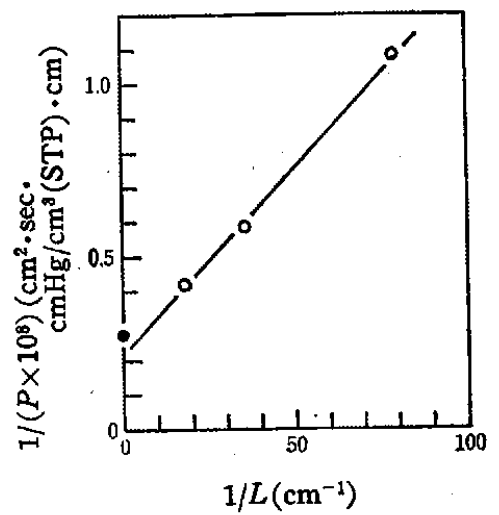

Fig. 6 Effect of thickness on permeability coefficients of polydimethylsiloxane membrane

: Permeability coefficient in dry state

数と乾嬠状熊にある膜の酸素透過係数の值が異なるときは, 共存 する水の膜への収着の結果生じる瞙構造の変化に起因すると考え られる。こうして, 水共存下での膜の酸素透過係数と䩐嬠状態に ある膜の酸素透過係数とを比較することによって，気体透過性に およぼす水の影鄉を観察することができる。

3.3.2 酸菜の透過係数，抬散係数に対する水共存の影響 : 表 1 で EVA1-34 膜について水蒸気の拡散原数が高い水蒸気圧下で 增加する傾向がみられたので，水の影響を明らかにするため，膜 が水で䭒和された状態での酸素の透過を測定した。表 3 に酸菜電 極を用いた場合（添字にWをつけて表わす）および膜が乾㷄状態 にある場合（添字にg をつけて表わす）の透過係数，拡散俰数お よび溶解度係数を比较して示した。念のために、拡散係数の比較 的大きいEVAC-13 膜について，前節で迢べた獏の厚さの影響を

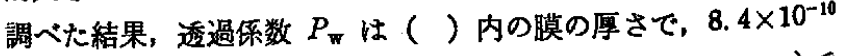
$(0.160 \mathrm{~mm}), 8.5 \times 10^{-10}(0.106 \mathrm{~mm}), 8.4 \times 10^{-10}(0.060 \mathrm{~mm})$ で あり，膜の厚さの違いによる透過係数に差異はなかった。

EVAc-13 膜括よび EVAc-34 膜では，就蜗状態での透過係数 に対する水共存での透過係数の比 $P_{\mathrm{w}} / P_{\mathrm{g}}$ の値が 1.4 であり，酸 素透過性に対して水の影響がさわめてわずかであることがわか 
Table 3 Effect of water on permeability coefficients, diffusion coefficients and solubility coefficients of oxygen

\begin{tabular}{|c|c|c|c|c|c|c|c|}
\hline Membrane & $P_{\mathrm{w}}^{a)}$ & $P_{\mathbf{g}}{ }^{a)}$ & $D_{\mathrm{w}}^{b)}$ & $D_{\mathrm{g}}{ }^{b)}$ & $S_{\mathrm{w}}{ }^{c)}$ & $S_{\mathrm{g}}{ }^{c)}$ & $P_{\mathrm{w}} / P_{\mathrm{g}}$ \\
\hline EVAc-13 & 8.4 & $5.9^{(d)}$ & 3.9 & $7.1^{d)}$ & 2.2 & $0.83^{d)}$ & 1.4 \\
\hline EVAl-13f & 0.46 & $0.30^{d\rangle}$ & 0.29 & $0.55^{d)}$ & 1.6 & $0.55^{d)}$ & 1.5 \\
\hline EVAc-34 & 1.9 & 1.4 & 0.30 & 0.32 & 6.3 & 4.3 & 1.4 \\
\hline EVA1-34 & 0.13 & 0.75 & 0.08 & 0.19 & 1.7 & 4.0 & 0.17 \\
\hline $\mathrm{PVA}^{e)}$ & 3.7 & 0.001 & 0.10 & & 37 & & 3700 \\
\hline Cellophane & 2.8 & 0.001 & 0.13 & & 22 & & 2800 \\
\hline
\end{tabular}

a) $\times 10^{-10}\left(\mathrm{~cm}^{3}(\mathrm{STP}) \cdot \mathrm{cm} / \mathrm{cm}^{2} \cdot \mathrm{sec} \cdot \mathrm{cmHg}\right)$

b) $\times 10^{-7}\left(\mathrm{~cm}^{2} / \mathrm{sec}\right)$

c) $\times 10^{-3}\left(\mathrm{~cm}^{3}(\mathrm{STP}) / \mathrm{cm}^{3} \cdot \mathrm{cmHg}\right)$

d) Data $f$ rom previous study ${ }^{4}$.

e) Poly (vinyl alcohol).

る。

比較のために用いた親水性高分子膜であるポリビニルアルコー ル膜就よびセロハンでは, $P_{\mathrm{w}} / P_{\mathrm{g}}$ の值が数千であり，水によって 大きな影䇾を受けることがわかる。

EVAl-34 膜では, $P_{\mathrm{w}} / P_{\mathrm{g}}$ の值が 0.17 であり, 水共存により 酸素透過係数がむしろ減少する結果を得た。これは $D_{\mathrm{w}}$ が $D_{\mathrm{g}}$ よ り小さいことおよび $S_{\mathrm{w}}$ が $S_{\mathrm{g}}$ より小さいことの両者に起因す

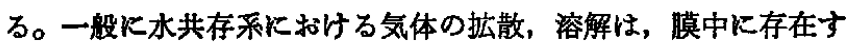
る水分子の存在状態水大きく影響を受けると考えられる。高分解 能 NMR を用いて，膜中に存在する水の状熊を調へたたところ， EVA1-34 膜ではベースラインがわずかにもり上がる程度の非常 に幅広いビークが得られ，水分子は極性基であるヒドロキシル基 に強く吸着しているすのと推察できる。しかしEVAc獏では水の 収着量が少ないため測定できず，定量的な議諭を行ならことがで きなかった。神谷ら゙)は，七ロハンの気体透過珄に対する水の影

14）神谷義紀，高橋文男，日本化学会第 29 年会講演予稿集， I, p. 301(1973).
響を研究し，乾燥状態にある膜への気体の溶解度俰数よりす相対 湿度が約 $70 \%$ 以下にある膜への気体の溶解度俰数の方が小さい といら結果を報告し，セルロースの分子間または分子内空隙部分 への水分子による充てんのためであると考察している。EVA1-34 膜では水の存在しないときには酸索の拡散領域に使われていた結

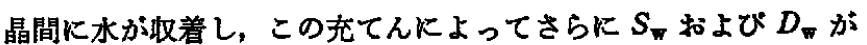
減少するるのと考兄られる。

一方，EVAl-13 f 膜では，無定形領域にあるとドロキシル基は 水素結合していて，乾煤状熊でるこの部分は不逅過性の領域であ り，わずかに水の収着量は増加してもこの水素結合を切るに十分 でなく，水の影響が現われないのであるら。

終りに試料を提供して下さいました三井石油化学株式会社, クラレ株式会社，実験に協力された石田与子棘に感謝いたしま す。

（1974 年 6 月，第 23 回高分子学会年次大会発表）

\title{
Effect of Water on Oxygen Permeation in Ethylene-Vinyl Acetate
} Copolymer Membranes and Their Hydrolyzed Membranes

\author{
Norihiko Minoura and Tsutomu Nakagawa \\ Industrial Products Research Institute; Shimomaruko, \\ Ota-ku, Tokyo 144 Japan
}

Ethylene-vinyl acetate copolymers containing 13.8 and $34.4 \mathrm{~mol} \%$ of vinyl acetate unit (EVAc-13 and EVAc-34, respectively) were used throughout this work. The EVAc-13 and EVAc-34 membranes were prepared from toluene solutions of the respective starting materials by evapolating the solvent on a glass plate at room temperature. The hydrolyzed membranes (EVAI-13f) were obtained by suspending the EVAc-13 membranes in a methanol solution of sodium methoxide for 20 hours at $20^{\circ} \mathrm{C}$; they were perfectly hydrolyzed. The other perfectly hydrolyzed polymer (EVAl-34) was prepared by the hydrolysis of EVAc-34 in a methanol solution of sodium methoxide, and EVAl-34 membranes were prepared by casting from dimethyl sulfoxide solutions.

The amounts of water sorbed by the EVAl-13 $\mathrm{f}$ and EVAl-34 membranes are more than those sorbed by the corresponding EVAc membranes. However, the permeability coefficients $(P)$ and the diffusion coefficients $(D)$ of water vapor in the EVAl-13 $\mathrm{f}$ and EVAl-34 membranes are much lower than those of the corresponding EVAc membranes. As increase in crystallinity of EVAl-13f membranes due to hydrolysis was not found, the reduction of $D$ in these membranes was ascribed to the changes of composition, namely to the immobility of polymer chains due to the formation of hydrogen bonding. However, in the case of EVAl-34 
membranes, the reduction of $D$ was ascribed to the formation of the new crystal consisting of vinyl alcohol unit.

An apparatus was developed for studying the effect of water on oxygen permeation through the membrane. The permeability coefficients of oxygen determined by this apparatus, $P_{\mathrm{w}}$, well agreed with those determined by the usual high vacuum method, $P_{\mathbf{g}}$, for hydrophobic polymer membranes except polydimethylsiloxane. The effect of water on oxygen permeation was elucidated by the comparison of $P_{\mathrm{W}}$ with $P_{\mathrm{g}}$. The values of $P_{\mathrm{w}} / P_{\mathrm{g}}$ for poly (vinyl alcohol) membrane, cellophane, EVAc membrane, EVAl-13f membrane and EVAl-34 membrane are $3700,2800,1.4,1.5$ and 0.17 , respectively. 